C O M U N IC AÇ Ã O B R E VE

\section{BALNEOLOGY AND HEALTH RESORT MEDICINE IN GERMANY}

\section{BALNEOLOGIA E ESTÂNCIAS HIDROMINERAIS NA ALEMANHA}

\begin{abstract}
The tradition of Health Resort Medicine and the use of balneological modalities is very strong in central Europe. The efficacy for many diseases has been shown. However, due to modern trends in the health system, the use of balneology has been reduced dramatically within the last ten to 20 years. However, in other European countries, especially in France, Italy, Spain, Hungary and Turkey, Balneotherapy is more and more supported by scientific research and similar to many Eastern European countries, it is still used for many chronic health conditions.
\end{abstract}

\section{KEYWORD}

Crenobalneotherapy.

Germany.

Thermalism.
CADERNOS DE

NATUROLOGIA

E TERAPIAS COMPLEMENTARES \& unsasu

Christoph Gutenbrunner

- MD, PhD, Professor. Department for Rehabilitation Medicine.Institute for Balneology and Medical Hydrology. Hannover Medical SchoolPhD Rheumatology Unit, Department of Medicine, Surgery and Neuroscience, University of Siena, Italy

CORRESPONDENTE

Christoph Gutenbrunner Hannover Medical School Carl-Neuberg-Str. 1

D-30625 Hannover Germany

Tel.: +49(0) 5115324100

Fax: +49(0) 5115324293

E-M A I L

gutenbrunner.christoph@mh-hannover.de

Recebido: 11/04/2014

Aprovado: 15/06/2014 


\section{RESUMO}

A tradição de estânciasmedicinaise o uso de modalidades balneologicas é muito forte na Europa central. A eficácia para muitas doenças tem sido demonstrada. No entanto, devido às tendências modernas no sistema de saúde, o uso da balneologia reduziu dramaticamente entre os últimos dez a vinte anos. Contudo, em outros países europeus, especialmente na França, Itália, Espanha, Hungria e Turquia, a balneoterapia está cada vez mais apoiada pela investigação científica, e similar a muitos países da Europa Oriental, ainda é usada para muitas condições crônicas de saúde.

PALAVRAS-CHAVE: Balneoterapia. Alemanha. Termalismo.

\section{INTRODUCTION}

In Central Europe the medical use of mineral water was known at least since the Roman Empire. However, even the old German traditions of ritual use of mineral water had some medical meaning, too. Documents about the medical evaluation of health resort medicine in Germany date back until the $17^{\text {th }}$ century. In those days, treatment concepts in health resorts had been designed based on the medical knowledge of this time. Later on, health resorts became centers of medicine, but were also used for relaxation and some cultural life, especially for the aristocracy and upper class. This in Germany changed near to the end of the $19^{\text {th }}$ century as the social insurance was established and the health resorts were opened to people from all parts of society.

As science in Germany has been part of Balneology already in early times, it is not surprising that the scientific society for Balneology was one of the first scientific medical societies and was first founded as Section of the Society of Internal Medicine in 1879. Since the 1920s, Balneology has been very active scientifically and was integrated part of university medicine. Especially in the 1950s, 1960s and 1970s, many physiological and clinical studies about the effects of the use of mineral waters, natural gases, and peloids were performed. The main principles of the effects both of chemical ingredients and of physical effects were investigated, and a modern concept of adaptation and plasticity has been developed based on scientific data (for an overview see Gutenbruner \& Hildebrandt $t^{l}$ ). The results from this research still are of relevance for the medical use of balneologic modalities. However, since about 20 years ago, the number of scientific institutes for Balneology, especially at universities, has been reduced dramatically. Today, almost no capacities or research in Balneology are available anymore. Specific funding for scientific work has been reduced to nearly zero. On the other hand, in some other European countries, scientific research, especially on clinical outcomes of comprehensive balneological treatments, is increasing; e.g. in France, Italy, Hungary and Turkey.

In parallel to this development in the medical community, balneological treatments were discussed more and more controversial ad it was postulated that "modern" rehabilitation concepts should replace "traditional" Balneolotherapy. However, the system of rehabilitation in fact was based on many of the factors that have been introduced by traditional health resort medicine, such as a combination of different treatments including relaxation, health education and use of environmental factors. However, the use of balneological treatments plays only a minor role in these concepts by many doctors more and more Balneology was seen as traditional or old-fashioned.

\section{DEFINITIONS}

In Germany, and other central European countries, definitions in balneotherapy and balneologic science have been very clear for centuries. Thus, the use of mineral water, peloids and natural gases was called "Balneotherapy", independent of the modality of use (bathing, drinking, inhalation and in some cases: irrigation). Most parts of this terminology was defi- 
ned already in the 20iesof the last century and used since then. These definitions contained a classification of mineral waters and peloids, too (for an overview see Gutenbruner \& Hildebrandt ${ }^{I}$ ). However, in Europe, terminology is very much different leading to some problems for the international publication of scientific results. For instance, in France, the term "Balneology" is used for the non-medical use of mineral waters, whereas "Crénotherapie" describes the medical use. In the UK, where no natural mineral waters are used for therapy anymore, the term "Hydrotherapy" is used for underwater exercise, whereas in Germany, this term is used for cold-water treatments according to Kneipp's treatment concept. To solve these problems, a proposal or a world-wide terminology has been published recently ${ }^{2}$. That, as a second step, could serve as a basis translation and into different languages and for adaptation to other countries.

Whereas Balneology and Hydrotherapy describe specific therapeutic interventions, the term "Health Resort Medicine" (in German: Kurortmedizin) describes the whole complex of potentially, medically relevant factors in health resorts as defined by Gutenbrunner \& Schuh ${ }^{3}$. Core elements of health resort therapy interventions are balneotherapy, hydrotherapy, and climatotherapy. Other interventions frequently used are massage, exercise, sauna, and other physical therapies e.g. kinesiotherapy, thermotherapy, electrotherapy, occupational therapy, medication, psychotherapy, nutrition (diet), health education and cognitive behavioural therapies, and relaxation therapies. Additionally a health promoting environment, recreational activities, cultural and social activities as well as sports are part of health resort medicine ${ }^{2}$.

In this concept, the definitions of therapy seem to be very clear. However, to describe the relevant contextual factors, such as climate, social environment and cultural activities, the International Classification of Functioning Disability and Health (ICF) may be used to define and classify them in an upto-date manner ${ }^{2}$. This classification and the recent research on the relevance of contextual factors to the participation of people with chronic diseases or disabilities, the traditional health resort concepts may be seen in a modern light.

In Germany, quality standards including threshold, methods of analyzing and quality control for infrastructure have been put down in the so-called "Begriffsbestimmungen und Qualitätsstandards für die Prädikatisierung von Kurorten, Erholungsorten und Heilbrunnen" ("Definitions and quality standards for spas, resorts and mineral springs"). They are updated regularly and are used framework for the control and legal acknowledgement of health resorts ${ }^{2}$. These quality standards are very useful, however, the given thresholds for mineral waters do not necessarily reflect thresholds for relevant physiological or therapeutical effects. For that reason, the research on effects on mineral waters, peloids and gases should be continued especially with respect to clinically relevant effects some of the being defined too ( $\underline{\text { table } \mathbf{1}})^{4}$.

Tab. 1. Electrolyte and gas concentration and minimum thresholds relevant for therapeutic effects of medicinal mineral waters (from Gutenbrunner \& Hildebrandt 1994)

\begin{tabular}{|c|c|c|}
\hline Name & Formula & $\begin{array}{l}\text { Threshold for } \\
\text { relevant effects }\end{array}$ \\
\hline \multicolumn{3}{|l|}{ Cations: } \\
\hline Sodium & $\mathrm{Na}+$ & *) \\
\hline Calcium & $\mathrm{Ca}++$ & $\left.300 \mathrm{mg} / \mathrm{l}^{* * *}\right)$ \\
\hline Magnesium & $\mathrm{Mg}++$ & $\left.150 \mathrm{mg} / \mathrm{l}^{* * *}\right)$ \\
\hline Iron & $\mathrm{Fe}++$ & $\left.20 \mathrm{mg} / \mathrm{l}^{\star * *}\right)$ \\
\hline \multicolumn{3}{|l|}{ Anions: } \\
\hline Chloride & $\mathrm{Cl}-$ & *) \\
\hline Hydrogen carbonate & HCO3-- & $\left.1.300 \mathrm{mg} / 1^{* * *}\right)$ \\
\hline Sulphate & SO4-- & $\left.1.200 \mathrm{mg} / \mathrm{l}^{* * *}\right)$ \\
\hline Fluoride & F- & $\left.1,0 \mathrm{mg} / \mathrm{l}^{* * *}\right)$ \\
\hline Iodide & $\mathrm{J}-$ & $\begin{array}{l}\left.1,0 \mathrm{mg} / \mathrm{l}^{\star * *}\right) \text { or } \\
\left.0,1 \mathrm{mg} / \mathrm{l}^{* * * *}\right)\end{array}$ \\
\hline \multicolumn{3}{|l|}{ Gases: } \\
\hline Carbon dioxide & $\mathrm{CO} 2$ & $\begin{array}{l}\left.500 \mathrm{mg} / \mathrm{l}^{\star *}\right) \text { or } \\
\left.1.000 \mathrm{mg} / \mathrm{l}^{\star * *}\right)\end{array}$ \\
\hline Hydrogen sulphide & $\mathrm{H} 2 \mathrm{~S}$ & $\left.10 \mathrm{mg} / \mathrm{l}^{\star \star}\right)$ \\
\hline Radon & $\mathrm{Rn}$ & $\left.666 \mathrm{~Bq} / 1^{\star * *}\right)$ \\
\hline \multicolumn{3}{|c|}{$\begin{array}{l}\text { *) Minimum threshold for brine bathes: } 240 \mathrm{mval} / \mathrm{l} \mathrm{NaCl}(=1,5 \%) \\
* *) \text { For bathing } \\
* * *) \text { For drinking } \\
{ }_{* * *)} \text { Prophylaxis of Iodine deficiency }\end{array}$} \\
\hline
\end{tabular}




\section{TREATMENT MODALITIES (BALNEOTHERAPY)}

As mentioned above, in Germany and other European countries, mineral waters, natural gases and peloids are used for treatment in Balneology and Health Resort Medicine therapy ${ }^{\text {iv }}$. Modalities of use of these substances are mainly bathing, drinking and inhalation. In France and other Roman speaking countries, the use for irrigations is very popular also.
The most important minerals; with relevant specific effects are Sodium Chloride, Calcium, Magnesium, Hydrogen Carbonate, Sulfate and some trace elements. Relevant gases (mostly dissolved in water) are Carbon Dioxide, $\mathrm{H}_{2} \mathrm{~S}$ and Radon. As peloids, peat, mud, and others are used, they mainly aim at some effects to discuss the effects of all these different types of interventions for the different indications cannot be described in detail here. However, table 2 gives an overview of the most important treatments in balneology as well as the main indications ${ }^{1,5}$.

Tab. 2. Indications for Balneotherapy (from Gutenbrunner \& Glaesener 2007)

\begin{tabular}{|c|c|c|}
\hline Field & Diagnosis & Modality \\
\hline \multirow{3}{*}{$\begin{array}{l}\text { Cardiovascular and } \\
\text { metabolic diseases }\end{array}$} & $\begin{array}{l}\text { Arterial hypertension, } \\
\text { Hyperlipaemia, Insulin } \\
\text { resistance }\end{array}$ & $\begin{array}{l}\text { Comprehensive spa treatment, CO2-bathing, } \\
\text { HCO3-drinking }\end{array}$ \\
\hline & $\begin{array}{l}\text { Microcirculatory dysfunction } \\
\text { (e.g. diabetic microangiopathia), } \\
\text { peropheral arterial occlusion }\end{array}$ & CO2-bathing \\
\hline & Chronic venous insufficiency & CO2-bathing \\
\hline \multirow{3}{*}{ Musculoskeletal disorders } & $\begin{array}{l}\text { Functional pain syndromes of } \\
\text { the locomotor system }\end{array}$ & $\begin{array}{l}\text { Thermoneutral and hyperthermic bathes, } \\
\text { hyperthermic peloid bathes or packs (in } \\
\text { combination with other interventions, such as } \\
\text { physiotherapy and others) }\end{array}$ \\
\hline & $\begin{array}{l}\text { Fibromyalgia and other Chronic } \\
\text { Generalised Pain Syndromes, } \\
\text { Rheumatoid Arthritis }\end{array}$ & H2S-bathing, under-water exercise \\
\hline & $\begin{array}{l}\text { Complex Regional Pain } \\
\text { Syndrome, (CRPS) }\end{array}$ & CO2-bathing \\
\hline Respiratory diseases & $\begin{array}{l}\text { Reduced airway clearance (Chronic } \\
\text { obstructive pulmonary disease) }\end{array}$ & $\begin{array}{l}\text { Inhalations with } \mathrm{NaCl}-, \mathrm{NaHCO}-\text { and } \mathrm{Ca}- \\
\text {-waters in combination with other therapies } \\
\text { (e.g. respiration exercises) }\end{array}$ \\
\hline Skin diseases & Psoriasis, neurodermatitis & $\begin{array}{l}\text { H2S-bathing, NaCl-bathing, in combination } \\
\text { with UV-radiation }\end{array}$ \\
\hline \multirow[t]{2}{*}{ Gastro-intestinal diseases } & Chronic functional bowel disorders & $\begin{array}{l}\text { Comprehensive spa treatment, HCO3- } \\
\text {-drinking (mainly gastric complaints) or Sul- } \\
\text { phate water drinking (gall bladder, pancreas } \\
\text { and related syndromes) }\end{array}$ \\
\hline & Chronic constipation & SO4-drinking \\
\hline \multirow[b]{2}{*}{$\begin{array}{l}\text { Renal and urinary tract } \\
\text { diseases }\end{array}$} & $\begin{array}{l}\text { Chronic and recurrent urinary } \\
\text { tract infections }\end{array}$ & $\mathrm{CO} 2-$ and Ca-water drinking \\
\hline & $\begin{array}{l}\text { Metaphylaxis of urinary } \\
\text { stone formation }\end{array}$ & $\begin{array}{l}\text { Dependent on type of calculi: HCO3-drinking } \\
\text { (uric acid an calcium-oxalate stones), Mg- } \\
\text {-drinking (calcium-containing stones), } \\
\text { Sulphate drinking (infection stones) }\end{array}$ \\
\hline Gynaecology & Chronic Pelvic Pain Syndrome & $\begin{array}{l}\text { Comprehensive spa treatment (specific gy- } \\
\text { naecologic modalities are: intra-vaginal peat } \\
\text { applications and brine irrigations) }\end{array}$ \\
\hline $\begin{array}{l}\text { Functional syndromes, } \\
\text { chronic fatigue syndrome }\end{array}$ & & Comprehensive spa treatment \\
\hline
\end{tabular}




\section{COMPREHENSIVE TREATMENT \\ CONCEPTS (HEALTH \\ RESORT MEDICINE)}

Based on the therapeutic use of mineral waters, gases and peloids, in health resorts comprehensive treatment concepts have been developed (see above). One most relevant factor is the change of environment including stress relief and change of social contacts. Another factor is climatic change that in many cases is useful for relief from stress (e.g. air pollution) or as therapeutic stimuli (e.g. climatic change). Of course the medical infrastructure is of major importance including the management by specifically educated doctors the availability of other therapies including diet, relaxation therapy and others. Last but not least cultural factors may be of relevance, too. In the Kneipp's comprehensive therapy concepts the latter are comprised as "Ordnungstherapie". The relevance of these factors are seen of major relevance. Besides of the specific treatments the environmental factors are seen as relevant for treatment and rehabilitation effects, too ${ }^{1,2}$.

Traditionally, patients go for six weeks into the health resorts. This duration of treatments has been justified and supported by research in adaption physiology ${ }^{1}$. Thus, many studies that have been performed in the last decades of the last century have shown that functional adaptation is one of the major mechanisms of health resort treatment. It is induced by therapeutic stimuli and leads to optimize regulation of autonomous functions and normalization of many clinically relevant body functions (e.g. blood pressure, metabolic function, respiratory functions, bowel and renal functions as well as immunological functions). However, due to financial pressure, the duration of health resort treatments (including rehabilitation for chronic diseases) now has been shortened to three weeks only. However, in Germany especially in psychosomatic disorders longer stays in health resorts are possible.

The efficacy of these complex treatments has been shown in many studies (for an overview see Gutenbrunner et al. ${ }^{2}$ ). For some indications (e.g. lower back pain, osteoarthritis, rheumatoid arthri- tis) even systematic reviews and metaanalyses are available now, showing good evidence for treatment outcomes $^{6,7,89,10,11,12}$. The duration of effects mostly lasts between six and twelve months.

\section{RECENT DEVELOPMENTS AND TRENDS}

As mentioned above, Balneology has a long tradition in Germany and a lot of scientific research has been done on the effects of balneologic treatments, as well as on comprehensive resort treatment concepts. However the use of Balneotherapy in Germany in the last decade has been reduced more and more. This tendency was caused by many reasons. The main reasons might be:

1) Other effective treatment concepts have been developed for many chronic diseases, e.g. diabetes, arterial hypertension, rheumatoid arthritis and chronic gastritis. For this reason, balneotherapy nowadays is less important for the treatment of such diseases.

2) In the 1990s, there were strong complaints among doctors and insurance companies that balneology is an old-fashioned, non-scientific type of treatment and should be replaced by modern rehabilitation concepts based on physiotherapy, occupational therapy, patient education and other specific interventions.

3) Even though the number of controlled trials on the efficacy of balneotherapy is increasing now (see above), the trend to reduce the use of balneotherapy is caused by a lack of scientific evidence, especially big studies performed in a prospective, controlled design. These standards as developed for outcome studies in pharmacology have some difficulties in Balneology and Health Resort Medicine as control groups are not easy to recruit and many balneologic modalities (e.g. bathing) cannot be applied in a double-blind way.

4) Economic reasons are of relevance, too: health insurances tend to shorten support in balneotherapy because of the general shortage of money in the health systems,. Nowadays, most of Health Resort Interventions are not covered by health insurance anymore. 
5) Last, but not least, health resorts themselves supported more and more wellness concepts and concentrated more on health tourism. The strong advertisement for these groups of users weakened the medical standard and representation in the medical community. For health resort manages, the marketing of wellness and health tourism seems to be much more attractive in comparison to the marketing for medical concepts.

Thus, it seems that Germany now follows the northern European way, excluding Balneotherapy more and more from the panel of medical interventions. However, in other parts of Europe, the situation seems to be much better. E.g. in France and Italy recently, new initiatives have been established to support clinical research in balneotherapy. At the same time, in these countries, the conflict between balneotherapy and rehabilitation concepts is not be-

\section{FONTE DE FINANCIAMENTO}

\author{
Nenhuma
}

\section{CONFLITO DE INTERESSES}

Declara não haver

\section{REFERENCES}

1. Gutenbrunner C, Hildebrandt G (Eds): Handbuch der Balneologie und medizinischen Klimatologie. Springer, Berlin-Heidelberg-New York-Tokyo 1998.

2. Gutenbrunner C, Bender T, Cantista P, Karagülle Z: A Proposal for a Worldwide Definition of Health Resort Medicine, Balneology, Medical Hydrology and Climatology. Int J Biometeorol 2010; 54 : 459-507.

3. Gutenbrunner C, Schuh A: Begriffsdefinitionen Medizinische Balneologie - Medizinische Klimatologie - Kurortmedizin. Phys Med Rehab Kuror 2002; 12: M13 - M14

4. Gutenbrunner C, Hildebrandt G: Handbuch der HeilwasserTrinkkuren - Theorie und Praxis. Sonntag, Stuttgart 1994

5. Gutenbrunner C: Balneotherapie. In: Gutenbrunner C, Glaesener JJ (Eds): Rehabilitation, Physikalische Medizin und Naturheilverfahren. Springer, Heidelberg 2007, p 85-90(48) Karagülle MZ, Karagülle M: Balneotherapy and spa therapy of rheumatic diseases in Turkey: a systematic review (Ger-man). Forschende Komplementarmedizin und Klassische Naturheilkunde 2004: 11: 33-41.

6. Devereux K, Robertson D, Briffa NK: Effects of a water-based program on women 65 years and over: a randomised controlled trial. Australian Journal of Physiotherapy 2005; 51: 102-108. ing discussed in such a controversial way. In eastern European countries, balneotherapy has a long tradition, also, and still is used. However, the discussion its significance for the health systems has been started only in the last ten years. Its consequences are therefore still open.

Summarizing, the tradition of Health Resort Medicine and the use of balneological modalities is very strong in central Europe. The efficacy for many diseases has been shown. However, due to modern trends in the health system, the use of balneology has been reduced dramatically within the last ten to 20 years. However, in other European countries, especially in France, Italy, Spain, Hungary and Turkey, Balneotherapy is more and more supported by scientific research and similar to many Eastern European countries, it is still used for many chronic health conditions.
7. Pittler MH, Karagülle MZ, Karagülle M, Ernst E: Spa therapy and balneotherapy for treating low back pain: meta-analysis of randomized trials. Rheumatology 2006; 45: 880-884.

8. Bartels EM, Lund H, Hagen KB, Dagfinrud H, Christensen R, Danneskiold-Samsoe B: Aquatic exercise for the treatment of knee and hip osteoarthritis. Cochrane Database of Systematic Reviews 2007; 4: CD005523.

9. Tomas-Carus P, Hakkinen A, Gusi N, Leal A, Hakkinen K, OrtegaAlonso A: Aquatic training and detraining on fitness and quality of life in fibromyalgia. Medicine \& Science in Sports \& Exercise 2007; 39: 1044-1050.

10. Verhagen AP, Bierma-Zeinstra SM, Boers M, Cardoso JR, Lambeck J, de Bie RA, de Vet HC: Balneotherapy for osteoarthritis. Cochrane Database of Systematic Reviews 2007; 4: CD006864.

11. Forestier R, Francon A: Crenobalneotherapy for limb osteoarthritis: systematic literature review and methodological analysis. Joint Bone Spine: Revue du Rhumatisme 2008; 75:138-148.

12. Hall J, Swinkels A, Briddon J, McCabe CS: Does aquatic exercise relieve pain in adults with neurologic or musculoskel-etal disease? A systematic review and meta-analysis of randomized controlled trials. Archives of Physical Medicine \& Rehabilitation 2008; 89: 873-883. 